\title{
SIMULTANEOUS OPTIMISATION OF DRYING PARAMETERS OF CERAMIC BODIES
}

\author{
${ }^{1}$ Salah Mahmoudi, ${ }^{2}$ Ezzeddine Srasra and ${ }^{3}$ Fouad Zargouni \\ ${ }^{1}$ Department of Earth Sciences, Faculty of Sciences of Gabes, 6072, Zrig, Gabes, Tunisia \\ ${ }^{2}$ Materials Center, Technopolis of Borj Cedria, BP95, 2050, Hammam Lif, Tunisia \\ ${ }^{3}$ Department of Geology, Faculty of Sciences of Tunis, 1060 Belvédère, Tunis, Tunisia
}

Received 2014-06-18; Revised 2014-06-25; Accepted 2014-07-01

\begin{abstract}
This study deals with the mineralogical, physico-chemical and geotechnical analyses of representative Aptian clays in the north-east of Tunisia. X-ray diffraction reveals a predominance of illite (50-60 wt.\%) associated to kaolinite and interstratified illite/smectite. The accessory minerals detected in raw materials are quartz, calcite and Na-feldspar. The average amounts of silica, alumina and alkalis are 52, 20 and 3.5 wt.\%, respectively. The contents of lime and iron vary between 4 and 8 wt.\%. Physical analyses show that the cation exchange capacity is $34.1-45.7 \mathrm{meq} / 100 \mathrm{~g}$ of air-dried clay. The plasticity test shows medium values of plasticity index (16-a28 wt.\%). The linear drying shrinkage is weak (less than 0.99 wt. \%) which makes these clays adapt to fast drying. The firing shrinkage and the expansion are limited. A lower firing and drying temperature can be translated into significant energy savings. Currently, these clays are used in the industrial process for the manufacturing of the earthenware tiles. For the better exploitation of the materials and improvement of production conditions, a mathematical formalism is established for the drying parameters. The regression models relate drying shrinkage (d), bending strength after drying (b) and residual moisture $(\mathrm{r})$ with the moisture $(\mathrm{m})$ and the pressing pressure $(\mathrm{p})$.
\end{abstract}

Keywords: Drying Parameters, Regression Models, Physiochemical Properties, Tunisia

\section{INTRODUCTION}

There are huge studies that develop the clays characterization used for ceramic products (e.g., Ibrahim et al., 2004; Monteiro and Vieira, 2004; Lisboa et al., 2007; Dondi et al., 2008; Mahmoudi et al., 2008; Meseguer et al., 2010; Diko et al., 2011). In addition, many researches deal with the transformations of clay materials by firing. Indeed, the reactions in the phyllosilicates and accompanying minerals like quartz, feldspar and calcite are decisive to establish the final properties of the ceramic bodies (e.g., Jordán et al., 1999; Carretero et al., 2002; Matteucci et al., 2002; Zanelli et al., 2003; Mao et al., 2006). The disappearance and the neomineralisation of mineral bodies, such as the formation of wollastonite, gehlenite and anorthite is the subject of many works (e.g., Cultrone et al., 2001; Mansur and Mansur, 2003; Aras, 2004; Sousa and
Hollanda, 2005; Cultrone et al., 2005; Ferrari and Gualtieri, 2006; Jordán et al., 2008; Jordán et al., 2009; Mahmoudi et al., 2010; Pardo et al., 2011). The influence of the heating rate on phase transformation and mullite formation is devoted by Castelein et al., 2001; Tulyaganov et al., 2002; Sedmale et al., 2006; Sahnoun et al., 2008). It's clear that the firing stage is important and decisive in the manufacturing of ceramic bodies, but this step is preceded by a drying stage, which can influence and affect the later stages of production (Tarì and Ferreira, 1998; Tarì et al., 1999). Few studies only are developed in this way. Indeed, the main steps of the drying process consist in the evaporation of the free-water, obtained from the green shaped bodies. Consequently, the particles approach each other, accompanied by shrinkage. The drying behaviour depends on the humidity or moisture (m) and the pressing pressure (p) required for shaping Corresponding Author: Salah Mahmoudi, Department of Earth Sciences, Faculty of Sciences of Gabes, 6072, Zrig, Gabes, Tunisia, Tel: +216 9765 55 81; Fax: +216 75392421 
(Carretero et al., 2002) and it is characterized by three parameters: drying shrinkage (d), bending strength after drying (b) and residual moisture (r). In this study tour approach is to determine regression models of (d), (b) and (r) as function of ( $\mathrm{p}$ ) and ( $\mathrm{m})$ is considered.

\section{MATERIALS AND METHODS}

The measurements of drying shrinkage (d), bending strength after drying (b) and residual moisture (r) were determined in industry conditions. The raw materials were crushed (residue through a $425 \mu \mathrm{m}$ sieve is less than 0.5 wt.\%), moistened ( 8 wt.\%), mixed and sieved ( $\varnothing 2 \mathrm{~mm})$ and then left to rest for $48 \mathrm{~h}$ to obtain homogeneous agglomerates. The paste was shaped by pressing and dried in an industrial fast horizontal roller drier (cycle $=12 \mathrm{~min}, \mathrm{~T}$ $\left.=240^{\circ} \mathrm{C}\right)$. Ten green specimens $(300 \times 75 \times 7 \mathrm{~mm})$ were collected to measure drying parameters for each according to the European Standard (ISO 10545). The linear drying shrinkage (d) was evaluated using the formula: $\mathrm{D}=$ $\left[\left(l_{\mathrm{g}}-\mathrm{l}_{\mathrm{d}}\right) / \mathrm{l}_{\mathrm{g}}\right] \times 100$, where $\mathrm{l}_{\mathrm{g}}$ and $\mathrm{l}_{\mathrm{d}}$ are the measured length of green and dried samples (ISO 10545-4). The bending strength (b) was measured with a three-point flexural method according to the norm ISO 10545-4. The average values of bending strength were calculated by the equation: $\mathrm{B}=3 \mathrm{FL} / 2 \mathrm{yz}^{2}$, where: $\mathrm{F}=$ breaking load $(\mathrm{kg}), \mathrm{L}=$ distance between supports $(\mathrm{L}=29.67 \mathrm{~mm}), \mathrm{y}=$ sample width $(\mathrm{mm}), \mathrm{z}=$ sample thickness $(\mathrm{mm})$. At the outgoing of the drier, the green ceramic bodies were weighed $\left(\mathrm{m}_{1}\right)$ and dried at $105^{\circ} \mathrm{C}$ until constant weight $\left(\mathrm{m}_{2}\right)$. The value of the residual moisture (r) was obtained as follows: $\mathrm{R}=\left[\left(\mathrm{m}_{1}-\mathrm{m}_{2}\right) / \mathrm{m}_{2}\right] \times 100$.

\section{RESULTS}

Illite is the main mineral (50-60 wt.\%) but other minerals; quartz, kaolinite, interstratified illite/smectite, calcite and feldspar, are present in small quantities. Next, this study reveals that the average amounts of $\mathrm{SiO}_{2}$ and $\mathrm{K}_{2} \mathrm{O}$ are 51.9 and 3.4 wt.\%, respectively. The amount of $\mathrm{Al}_{2} \mathrm{O}_{3}$ is in average of 19.6 wt.\%. The contents of $\mathrm{CaO}$ vary between 4 and $8 \mathrm{wt} . \%$. The average amounts of $\mathrm{Fe}_{2} \mathrm{O}_{3}$ is 6 wt. \%. The grain size data indicate a siltdominated assemblage. The value for plasticity index ranges from 16 to $28 \mathrm{wt} . \%$. The firing shrinkage and the expansion are limited. The cation exchange capacity is $34.1-45.7 \mathrm{meq} / 100 \mathrm{~g}$ of air-dried clay.

According to (Ferrari and Gualtieri, 2006), who used illitic clays for traditional ceramic and showed that the high amount of illite is necessary in ceramic mixtures but it provokes a larger percentage of glass phase, lower water absorption and a higher linear shrinkage, thus the addition of a degreaser (sands, crushed glass, grogs, feldspars, pegmatite and chamotte; the latter is made up of brick debris and biscuit waste) is necessary to reduce the plasticity and the linear shrinkage, to improve water absorption and makes the clays easy to dry. To judge the quality of ceramic paste, the mixture used to produce the ceramic bodies is composed of $80 \%$ of Aptian clays and $20 \%$ of chamotte.

\section{DISCUSSION}

With reference to the data obtained (Table 1), regression models can be thought for the drying parameters measured at different pressures (p) and moistures (m).

The mathematical Equation 1-3 are proposed in their canonical form as second-degree polynomials these Equations can further relate drying shrinkage (d), bending strength after drying (b) and residual moisture $(\mathrm{r})$ with the moisture $(\mathrm{m})$ and the pressure $(\mathrm{p})$. The mathematic model is valid, when the error (difference between measured and calculated values) is uncorrelated and randomly distributed with a zero mean value and a common variance (Cornell, 2002; Myers and Montgomery, 2002; Correia et al., 2003).

$$
\begin{aligned}
& \mathrm{d}(\mathrm{m}, \mathrm{p})=\sum_{i=0}^{n} \alpha_{\mathrm{i}} \mathrm{m}^{\mathrm{i}} \mathrm{p}^{\mathrm{n}-1} \\
& \mathrm{~b}(\mathrm{~m}, \mathrm{p})=\sum_{i=0}^{n} \beta_{\mathrm{i}} \mathrm{m}^{\mathrm{i}} \mathrm{p}^{\mathrm{n}-1} \\
& \mathrm{r}(\mathrm{m}, \mathrm{p})=\sum_{i=0}^{n} \lambda_{1} \mathrm{~m}^{\mathrm{i}} \mathrm{p}^{\mathrm{n}-1}
\end{aligned}
$$

where, d: Drying shrinkage; b: Bending strength after drying; $r$ : Residual moisture; $\mathrm{m}$ is the wt.\% of moisture (humidity); $\mathrm{p}$ is the pressing pressure (bar) applied upon the paste; $\alpha_{i} \in \mathbb{R} ; \beta_{i} \in \mathbb{R} ; \lambda_{i} \in \mathbb{R}$ and $i \in\left[\begin{array}{ll}0 & 2\end{array}\right]$.

The experiment results are used to calculate the coefficients of the regression equations relating $d, b$ and $r$ with the values of $\mathrm{m}$ and $\mathrm{p}$. The calculations are carried out with MATLAB 7.5.0:

$$
\begin{aligned}
& \mathrm{d}(\mathrm{m}, \mathrm{p})=-0.0006 \mathrm{p}^{2}+0.5220 \mathrm{~m}^{2}+0.0006 \mathrm{pm} \\
& +0.1858 \mathrm{p}-5.5357 \mathrm{~m}+1.1601 \\
& \mathrm{~b}(\mathrm{~m}, \mathrm{p})=-0.0117 \mathrm{p}^{2}+7.2409 \mathrm{~m}^{2}-0.0082 \mathrm{pm} \\
& +4.9724 \mathrm{p}-90.2445 \mathrm{~m}-234.5912 \\
& \mathrm{r}(\mathrm{m}, \mathrm{p})=-0.0023 \mathrm{p}^{2}+1.5080 \mathrm{~m}^{2}-0.0005 \mathrm{pm} \\
& +0.9707 \mathrm{p}-18.2315 \mathrm{~m}-44.2979
\end{aligned}
$$


The Equation 4 to 6 are the final results and the values obtained from these mathematical models show that $\mathrm{d}, \mathrm{b}$ and $\mathrm{r}$ are $0.35-0.92 \mathrm{wt} . \%, 0.51-2.23 \mathrm{~N} / \mathrm{mm}^{2}$ and 0.01-1.43 wt.\%, respectively. The significance and the validity of the mathematical models can also be evaluated by comparing the experimental and the calculated values (Table 2). The difference between these values is low. It is on average $0.03 \%$ for drying shrinkage, $0.32 \mathrm{~N} / \mathrm{mm}^{2}$ for bending strength, or $0.01 \%$ for residual moisture. Diagrams (Fig. 1) show tolerable correlations between variables $\left(\mathrm{R}^{2}=0.989\right.$ for $\mathrm{d}, \mathrm{R}^{2}=$ 0.986 for $b$ and $R^{2}=0.982$ for $r$ ). However, the prediction is good for all cases of drying shrinkage (d), bending strength (b) and residual moisture (r).

The margin of error between the calculated and the measured values is less than $0.07 \mathrm{wt} . \%, 0.77 \mathrm{~N} / \mathrm{mm}^{2}$ and 0.36 wt. \% for $\mathrm{d}, \mathrm{b}$ and $\mathrm{r}$, respectively. This suggests that the developed model is valid, since the predicted values are consistent with the results obtained from experimental results and the regression equations are considered statistically significant.

The 3D plots are the graphical representation of the Equation 4 to 6 and allow for easy and rapid predictive estimate over the entire properties under investigation. Figure 2 and 3 show that $b$ and $r$ increase with the increase of $(\mathrm{p})$ and $(\mathrm{m})$ amounts.

On the contrary, the drying shrinkage (d) is conversely proportional to the pressure (p) and moisture (m) values (Fig. 4). Indeed, an important compaction of the paste reduces the movement of the particles.

Moreover, when the evaporation is incomplete and part of water quantity stays in the pores it can prevent the drying shrinkage. Another way of visualizing the effect that changes in drying parameters ( $\mathrm{p}$ and $\mathrm{m}$ ) might have on the $\mathrm{d}, \mathrm{b}$ and $\mathrm{r}$ and prove the interpretation of the statistical results through the use of response plots. In this way, the effect of each property can be visualized.
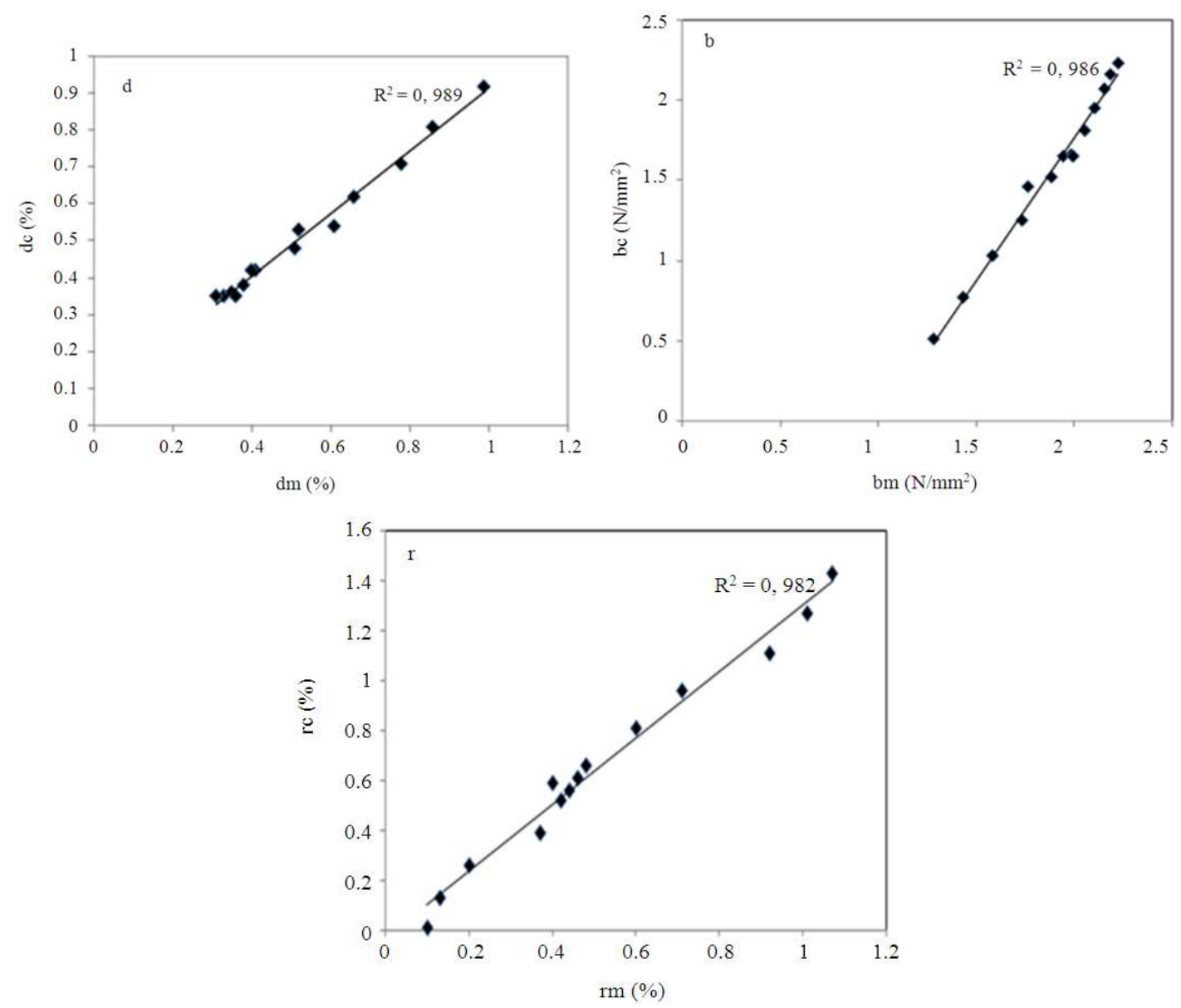

Fig. 1. Correlations between measured and calculated values, (d) drying shrinkage, (b) bending strength and (r) residual moisture 
Salah Mahmoudi et al. / American Journal of Geosciences 4 (1): 1-7, 2014

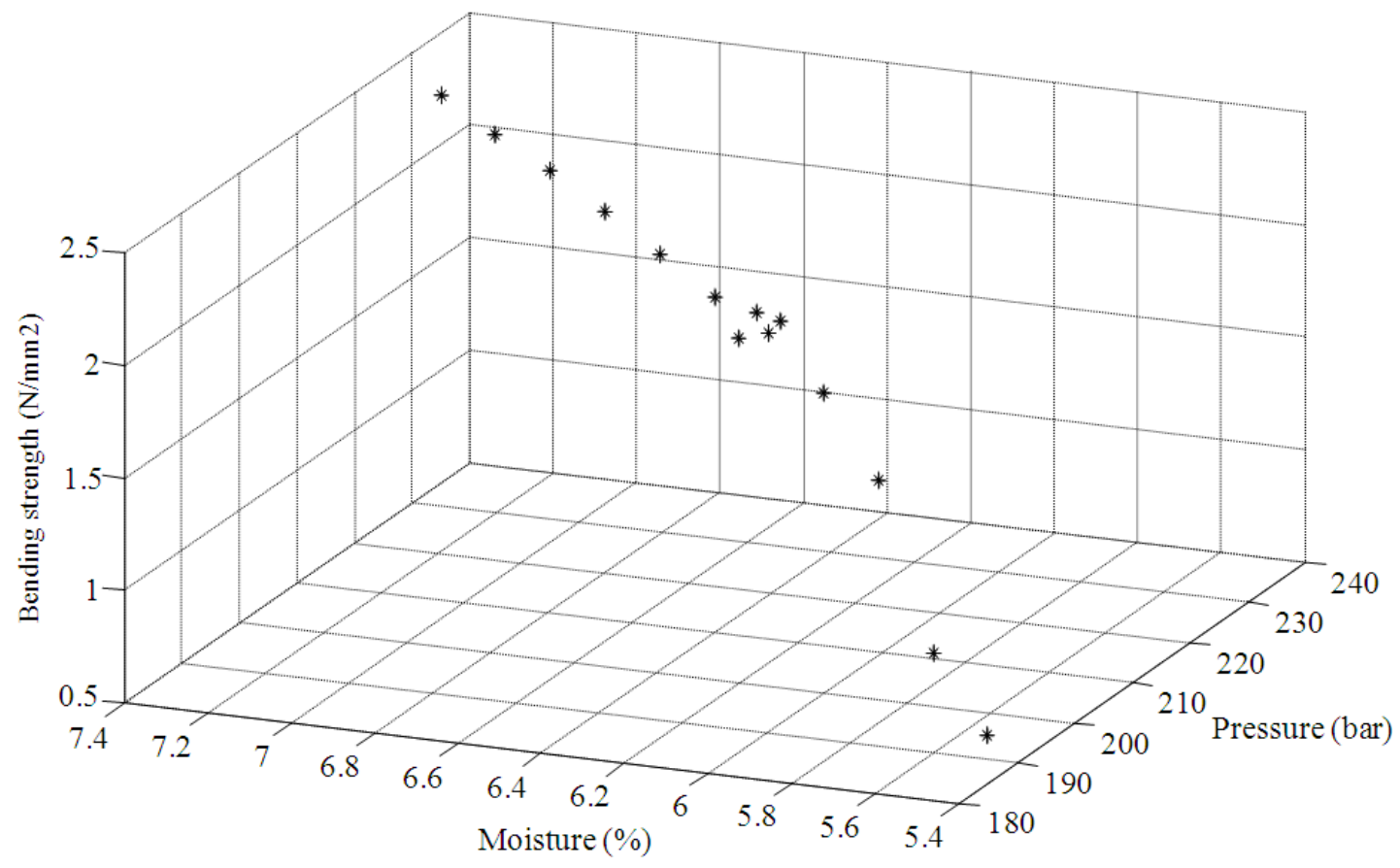

Fig. 2. 3D plot of bending strength as function as the amounts of pressure and moisture

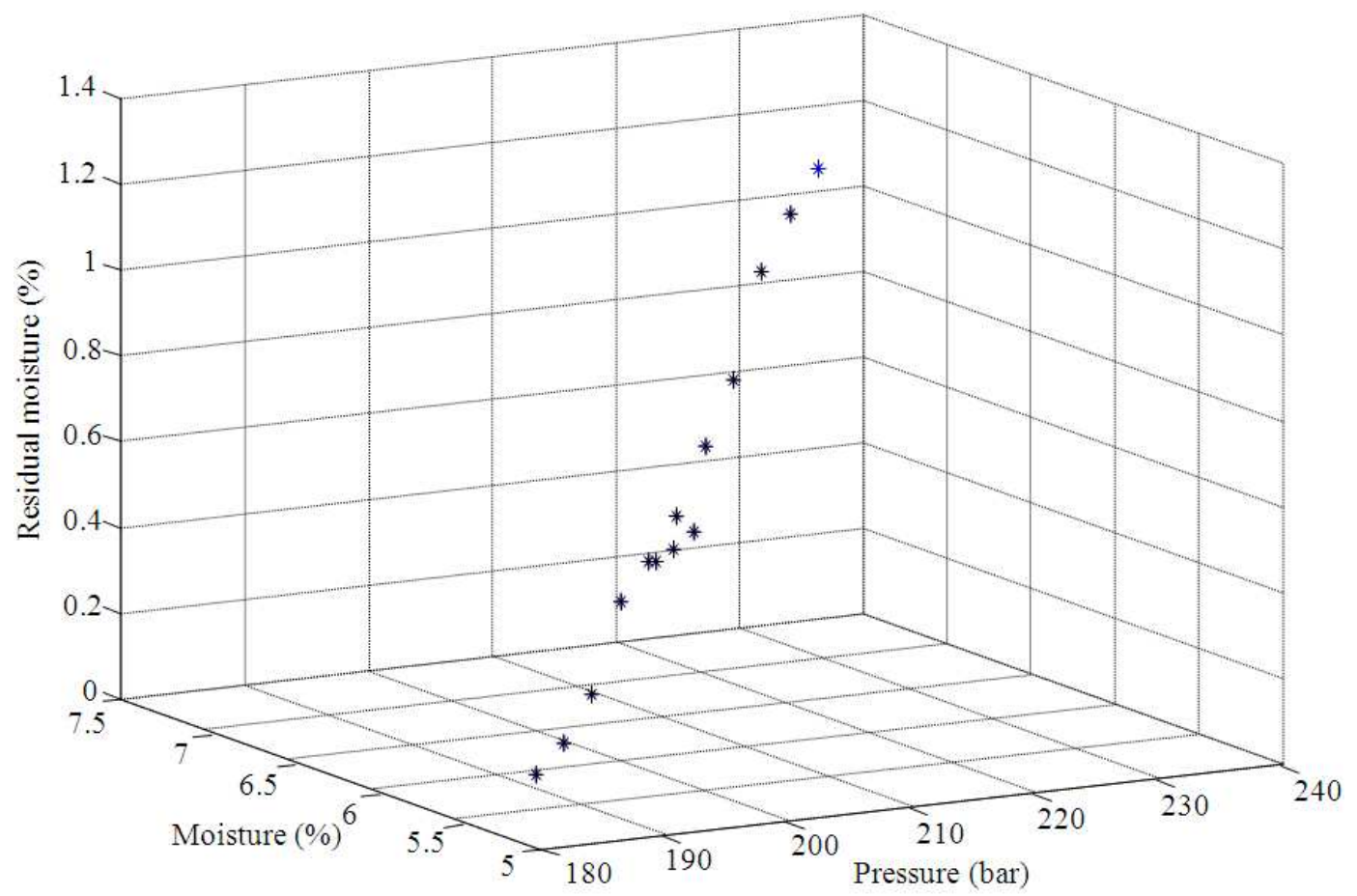

Fig. 3. 3D plot of residual moisture as function as the amounts of pressure and moisture 


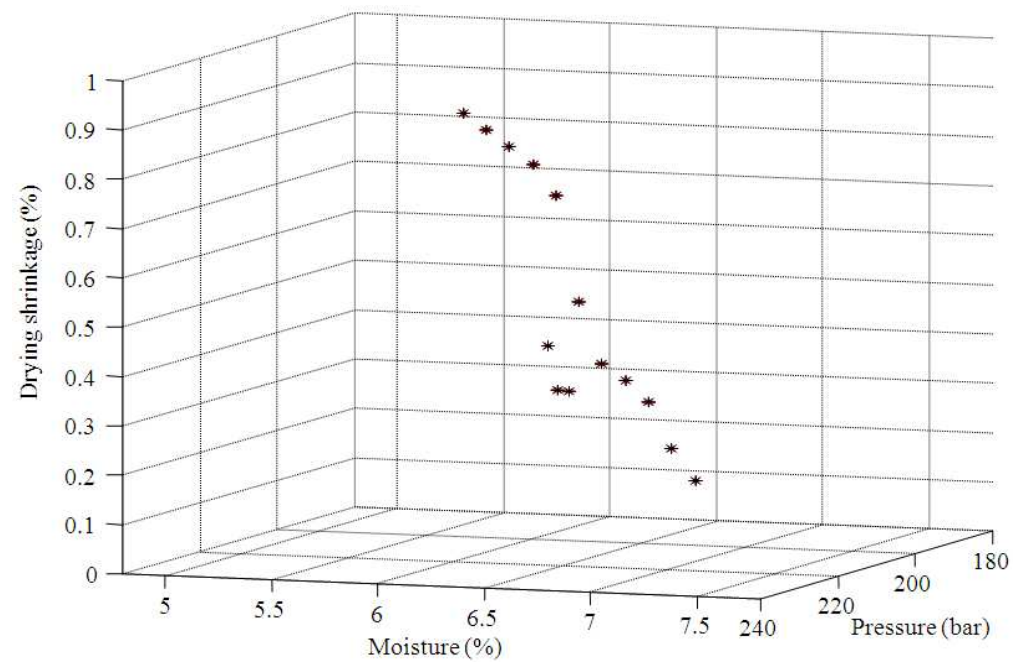

Fig. 4. 3D plot of drying shrinkage as function as the amounts of pressure and moisture

Table 1. The drying parameters: drying shrinkage (d), bending strength after drying (b), residual moisture (r) and pressure (p) applied upon the paste and moisture $(\mathrm{m})$ of paste before drying

\begin{tabular}{llllll}
\hline Pieces & $\begin{array}{l}\text { Pressure: } \\
\mathrm{p}\left(\mathrm{Kg} / \mathrm{cm}^{2}\right)\end{array}$ & $\begin{array}{l}\text { Moisture: } \\
\mathrm{m}(\%)\end{array}$ & $\begin{array}{l}\text { Drying shrinkage: } \\
\mathrm{d}(\%)\end{array}$ & $\begin{array}{l}\text { Bending strength } \\
\mathrm{b}:\left(\mathrm{N} / \mathrm{mm}^{2}\right)\end{array}$ & $\begin{array}{l}\text { Residual moisture: } \\
\mathrm{r}(\%)\end{array}$ \\
\hline 1 & 185 & 5.4 & 0.99 & 1.28 & 0.10 \\
2 & 190 & 5.6 & 0.86 & 1.43 & 0.13 \\
3 & 195 & 5.8 & 0.78 & 1.58 & 0.20 \\
4 & 200 & 6.0 & 0.66 & 1.73 & 0.37 \\
5 & 205 & 6.2 & 0.61 & 1.76 & 0.42 \\
6 & 207 & 6.2 & 0.41 & 1.98 & 0.44 \\
7 & 207 & 6.3 & 0.52 & 1.88 & 0.40 \\
8 & 210 & 6.3 & 0.33 & 1.94 & 0.48 \\
9 & 210 & 6.4 & 0.51 & 1.99 & 0.60 \\
10 & 215 & 6.6 & 0.40 & 2.05 & 0.71 \\
11 & 220 & 6.8 & 0.38 & 2.10 & 0.92 \\
12 & 225 & 7.0 & 0.35 & 2.15 & 1.01 \\
13 & 230 & 7.2 & 0.31 & 2.18 & 1.07 \\
\hline
\end{tabular}

Table 2. The errors between measured and calculated values: Drying shrinkage measured $\left(\mathrm{d}_{\mathrm{m}}\right)$, drying shrinkage calculated $\left(\mathrm{d}_{\mathrm{c}}\right)$, bending strength measured $\left(\mathrm{b}_{\mathrm{m}}\right)$, bending strength calculatecd $\left(\mathrm{b}_{\mathrm{c}}\right)$, residual moisture measured $\left(\mathrm{r}_{\mathrm{m}}\right)$ and residual moisture calculated $\left(r_{c}\right)$

\begin{tabular}{llllllllll}
\hline Pieces & $\mathrm{d}_{\mathrm{m}}(\%)$ & $\mathrm{d}_{\mathrm{c}}(\%)$ & $\begin{array}{l}\text { Error } \\
\left|\mathrm{d}_{\mathrm{c}}-\mathrm{d}_{\mathrm{m}}\right|(\%)\end{array}$ & $\mathrm{b}_{\mathrm{m}}\left(\mathrm{N} / \mathrm{mm}^{2}\right)$ & $\mathrm{b}_{\mathrm{c}}\left(\mathrm{N} / \mathrm{mm}^{2}\right)$ & $\begin{array}{l}\text { Error } \\
\left|\mathrm{b}_{\mathrm{c}}-\mathrm{b}_{\mathrm{m}}\right|\left(\mathrm{N} / \mathrm{mm}^{2}\right)\end{array}$ & $\mathrm{r}_{\mathrm{m}}(\%)$ & $\begin{array}{l}\mathrm{r}_{\mathrm{c}}(\%) \\
\left|\mathrm{b}_{\mathrm{c}}-\mathrm{b}_{\mathrm{m}}\right|(\%)\end{array}$ \\
\hline 1 & 0.99 & 0.92 & 0.07 & 1.28 & 0.51 & 0.77 & 0.10 & 0.01 & 0.09 \\
2 & 0.86 & 0.81 & 0.05 & 1.43 & 0.77 & 0.66 & 0.13 & 0.13 & 0.00 \\
3 & 0.78 & 0.71 & 0.07 & 1.58 & 1.03 & 0.55 & 0.20 & 0.26 & 0.06 \\
4 & 0.66 & 0.62 & 0.04 & 1.73 & 1.25 & 0.48 & 0.37 & 0.39 & 0.02 \\
5 & 0.61 & 0.54 & 0.07 & 1.76 & 1.46 & 0.30 & 0.42 & 0.52 & 0.10 \\
6 & 0.41 & 0.42 & 0.01 & 1.98 & 1.66 & 0.32 & 0.44 & 0.56 & 0.12 \\
7 & 0.52 & 0.53 & 0.01 & 1.88 & 1.52 & 0.36 & 0.40 & 0.59 & 0.19 \\
8 & 0.33 & 0.35 & 0.02 & 1.94 & 1.65 & 0.29 & 0.46 & 0.61 & 0.15 \\
9 & 0.51 & 0.48 & 0.03 & 1.99 & 1.65 & 0.34 & 0.48 & 0.66 & 0.18 \\
10 & 0.40 & 0.42 & 0.02 & 2.05 & 1.81 & 0.24 & 0.60 & 0.81 & 0.21 \\
11 & 0.38 & 0.38 & 0.00 & 2.10 & 1.95 & 0.15 & 0.71 & 0.96 & 0.25 \\
12 & 0.35 & 0.36 & 0.01 & 2.15 & 2.07 & 0.08 & 0.92 & 1.11 & 0.19 \\
13 & 0.31 & 0.35 & 0.04 & 2.18 & 2.16 & 0.02 & 1.01 & 1.27 & 0.26 \\
14 & 0.36 & 0.35 & 0.01 & 2.22 & 2.23 & 0.01 & 1.07 & 1.43 & 0.36
\end{tabular}




\section{CONCLUSION}

The studied raw materials collected from Aptian clays of Jebel Ressas (north-east Tunisia) show as dominant mineral illite, with accessory phase of quartz, kaolinite, calcite, illite-smectite mixed layers and $\mathrm{Na}-$ feldspar. Chemical analysis indicates that these clays are rich in silica, alumina and alkalis. A significant amount of iron oxides is also detected. Physical analyses show that the cation exchange capacity is $34.10-45.7 \mathrm{meq} / 100 \mathrm{~g}$ of air-dried clay. The plasticity test shows medium values of plasticity index (16-28 wt.\%). The linear drying shrinkage is weak (less than 0.82 wt.\%) which makes these clays adapt to fast drying. The firing shrinkage and the expansion are limited. A lower firing and drying temperature can be translated into significant energy savings. The ceramic properties and industrial tests show appropriate industrial characteristics of these clays, which enable to find application in the production of bricks and earthenware tiles. On the other hand, regression models are established to quantify the amounts of drying parameters (drying shrinkage, bending strength after drying and residual moisture) as function as pressure applied upon the paste and moisture. The developed model is based overall on measured values of the drying parameters. These models could be instructive for specialists in geotechnical and industrial applications.

\section{ACKNOWLEDGEMENT}

Thin sections were made and analyzed using the laboratory of the Materials Center in Technopolis of Borj Cedria. I am grateful to the Pr. Ezeddine SRASRA which partly supported this study.

\section{REFERENCES}

Aras, A., 2004. The change of phase composition in kaolinite-and illite-rich clay-based ceramic bodies. Applied Clay Sci., 24: 257-269. DOI: 10.1016/j.clay.2003.08.012

Carretero, M.I., M.C.B. Fabbri and M. Raimondo, 2002. The influence of shaping and firing technology on ceramic properties of calcareous and non-calcareous illitic-chloritic clays. Applied Clay Sci., 20: 301306. DOI: 10.1016/S0169-1317(01)00076-X

Castelein, O., B. Soulestin, J.P. Bonnet and P. Blanchart, 2001. The influence of heating rate on the thermal behaviour and mullite formation from a kaolin raw material. Ceram. Int., 27: 517-522. DOI: 10.1016/S0272-8842(00)00110-3
Cornell, J.A., 2002. Experiments with Mixtures: Designs, Models and the Analysis of Mixtures Data, 3rd End., John Wiley and Sons, New York, ISBN10: 0471393673, pp: 680.

Correia, S.L., D. Hotza and S.A. Segadães, 2003. Simultaneous optimization of linear firing shrinkage and water absorption of triaxial ceramic bodies using experiments design. Ceram. Int., 30: 917-922. DOI: 10.1016/j.ceramint.2003.10.013

Cultrone, G., N.C.E. Rodriguez, O. Cazalla and M.J. De La Torre, 2001. Carbonate and silicate phase reactions during ceramic firing. Eur. J. Mineral., 13: 621-634. DOI:10.1127/0935-1221/2001/0013-0621

Cultrone, G., E. Sebastián, K. Elert, D.L. Torre, M.J.O. Cazalla et al., 2005. Influence of mineralogy and firing temperature on the porosity of bricks. J. Eur. Society, 24: 547-564. DOI: 10.1016/S09552219(03)00249-8

Diko, M.L., G.E. Ekosse, S.N. Ayonghe and E.B. Ntasin, 2011. Physical characterization of clayey materials from tertiary volcanic cones in Limbe (Cameroon) for ceramic applications. Applied Clay Sci., 51: 380384. DOI: 10.1016/j.clay.2010.11.034

Dondi, M., C. Iglsias, E. Dominguez, G. Guarini and M. Raimondo, 2008. The effect of kaolin properties on their behaviour in ceramic processing as illustrated by a range of kaolins from the Santa Cruz and Chubut Provinces, Patagonia (Argentina). Applied Clay Sci., 40: 143-158. DOI: 10.1016/j.clay.2007.07.003

Ferrari, S. and A.F. Gualteri, 2006. The use of illitic the production stoneware tile ceramics. Applied Clay Sci., 32: 73-81.

Ibrahim, D.M., D.A. Abdel Aziz, S.A. Awad and A.M. Abdel Monem, 2004. Utilization of black shales in earthenware recipes. Ceramics Int., 30: 829-835. DOI: 10.1016/j.ceramint.2003.09.018

Jordán, M.M., A. Boix, T. Sanfeliu and C. de la Fuente, 1999. Firing transformations of cretaceous clays used in the manufacturing of ceramic tiles. Applied Clay Sci., 14: 225-234. DOI: 10.1016/S01691317(98)00052-0

Jordan, M.M., M.A. Montero, S. Meseguer and T. Sanfeliu, 2008. Influence of firing temperature and mineralogical composition on bending strength and porosity of ceramic tile bodies. Applied Clay Sci., 42: 463-477. DOI: 10.1016/j.clay.2008.01.005

Jordán, M.M., M.A. Montero, S. Meseguer and T. Sanfeliu, 2009. Mineralogy and firing transformations of Permo-Triassic clays used in the manufacturing of ceramic tile bodies. Applied Clay Sci., 42: 463-77. DOI: 10.1016/j.clay.2009.01.018 
Lisboa, J.V., J.M.F. Carvalho, A. Oliveira, C. Carvalho and J. Grade, 2007. A preliminary case study of potential ceramic raw materials in the Aileu area of Timor Leste. J. Asian Earth Sci., 29: 593-603. DOI: 10.1016/j.jseaes.2006.04.003

Mahmoudi, S., E. Srasra and F. Zargouni, 2008. The use of Tunisian Barremian clay in the traditional ceramic industry: Optimization of ceramic properties. Applied Clay Sci., 42: 125-129. DOI: 10.1016/j.clay.2007.12.008

Mahmoudi, S., E. Srasra and F. Zargouni, 2010. Firing behaviour of the lower cretaceous clays of Tunisia. J. African Earth Sci., 58: 235-241. DOI: 10.1016/j.jafrearsci.2010.03.004

Mansur, A.A.P. and H.S. Mansur, 2003. Microstructural of ceramic tiles. Proceedings of the 19th Congress of Brasilian Society of Microscopy and Microanalyses, (SMM' 03), Acta Microscopic, pp: 85-86.

Mao, H. M. Hillert, M. Selleby and B. Sundman, 2006. Thermodynamic Assessment of the CaO-Al2O3SiO2 System. J. Am. Ceram. Society, 89: 29-308. DOI: $10.1111 /$ j.1551-2916.2005.00698.x

Matteucci, F., M. Dondi and G. Guarini, 2002. Effect of soda-lime glass on sintering and technological properties of porcelain stoneware tiles. Ceram. Int., 66: 401-408. DOI: 10.1016/S0272-8842(02)00067-6

Meseguer, S., F. Pardo, M.M. Jordan, T. Sanfeliu and I. Gonzàles, 2010. Ceramic behaviour of five Chilean clays which can be used in the manufacture of ceramic tile bodies. Applied Clay Sci., 47: 372-377. DOI: 10.1016/j.clay.2009.11.056

Monteiro, S.N. and C.M.F. Vieira, 2004. Influence of firing temperature on the ceramic properties of clays from Campos dos Goytacazes, Brazil. Applied Clay Sci., 27: 229-234. DOI: 10.1016/j.clay.2004.03.002

Myers, R.H. and D.C. Montgomery, 2009. Response Surface Methodology: Process and Product Optimization Using Designed Experiments.1st Edn., John Wiley and Sons, New York, ISBN-10: 0470174463, pp: 680.
Pardo, F., S. Meseguer, M.M. Jordán, T. Sanfeliu and I. Gonzàles et al., 2011. Firing transformations of Chilean clays for the manufacture of ceramic tile bodies. Applied Clay Sci., 51: 147-150. DOI: 10.1016/j.clay.2010.11.022

Sahnoun, F., M. Chegaar, N. Saheb, P. Goeuriot and F. Valdivieso, 2008. Algerian kaolinite used for mullite formation. Applied Clay Sci., 38: 304-310. DOI: 10.1016/j.clay.2007.04.013

Sedmale, G., I. Sperberga, U. Sedmalis and Z. Valancius, 2006. Formation of high-temperature crystalline phases in ceramic from illite clay and dolomite. J. European Ceramic Society, 2: 3351-3355. DOI: 10.1016/j.jeurceramsoc.2005.10.012

Sousa, S.J.G. and J.N.F. Holanda, 2005. Development of red wall tiles by the dry process using Brazilian raw materials, Ceram. Int., 31:215-222. DOI: 10.1016/j.ceramint.2004.05.003

Tarì, G. and J.M.F. Ferreira, 1998. Influence of solid loading on drying-Shrinkage behaviour of slip cast bodies. J. Eur. Ceram. Society, 18: 487-493. DOI: 10.1016/S0955-2219(97)00161-1

Tarì, G., J.M.F. Ferreira and A.T. Fonseca, 1999. Influence of particle size and particle size distribution on drying-shrinkage behaviour of alumina slip cast bodies. Ceram. Int., 25: 577-580. DOI: 10.1016/S0272-8842(98)00068-6

Tulyaganov, D.U., M.H. Olhero, M.J. Ribeiro, J.M.F. Ferreira and J.A. Labrincha, 2002. Mullite-alumina refractory ceramics obtained from mixtures of natural common materials and recycled Al-rich anodizing sludge. J. Mat. Synt. Process., 10: 311318. DOI: $10.1023 / \mathrm{A}: 1023829601833$

Zanelli, C., M. Dondi, M. Raimondo, L. Beccaluva and C. Vaccaro, 2003. Phase transformations during liquid phase sintering of porcelain stoneware tiles: A petrological approach. Proceedings of the SINTERING International Conference on the Science, Technology and Applications of Sintering, Sep. 15-17, Penn State College, USA, Contributo. 